\title{
複数の差動磁気出力と DOG フィルタリングによる磁気探査装置の探査
} 能力の向上

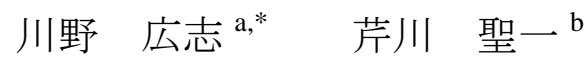

\section{Improvement of Search Ability of Magnetic Exploration Device Using Differential Magnetic Sensors and DOG Filtering \\ Hiroshi Kawano $^{\mathrm{a},{ }^{*},}$, Seiichi Serikawa ${ }^{\mathrm{b}}$}

(Received June 11, 2014; revised June 17, 2014; accepted June 19, 2014)

\begin{abstract}
Currently, unexploded ordnances have been still buried in the ground. It is important to detect and remove them. Although the devices to detect them exist, it causes fault detection if there exist a building near unexploded ordnance. To solve the problem, a magnetic device with plural differential outputs has been developed. In this method, the influence of magnetic field generated from building is reduced. However, if the magnetic field from the area is strong, the detection is sometimes failed. In addition, it is sometimes difficult to detect unexploded ordnances if the size changed. To solve these problems, a method using differential outputs and DOG filtering is proposed in this study. By the use of DOD and DOG functions, the location of unexploded ordnance is specified easily. Even if magnetic field from building is strong and the size of the unexploded ordnance is different, it is detected correctly. These are confirmed by the simulation.
\end{abstract}

キーワード : 不発弾, 磁気探査, 磁気探査装置

Keywords : unexploded ordnance, Magnetic exploration, magnetic detecting device, DOG function.

\section{1.はじめに}

第二次世界大戦中, 大規模な空襲により日本には多く の爆弾が投下された。その全てが爆発したわけではなく, そのような爆弾は不発弾と呼ばれている。特に激しい地 上戦が行われた沖縄では, 航空機爆弾, 艦砲射撃, 陸上 砲撃による不発弾が未だ身近に存在している(1-2)。この理 由から沖縄では, 安全を保つため不発弾の探査が頻繁に 行われている(3-4)。

不発弾探査には, 電磁誘導方式と差動型の磁気探査方

* Corresponding author. E-mail: kawano@mticorp.co.jp

a 株式会社エムティアイ

干 805-8503 福岡県北九州市八幡東区枝光 2-1-15

MTI Co., Ltd.

2-1-15, Edamitsu, Yahata-higashi, Kitakyushu, Fukuoka, Japan $805-8503$

b 九州工業大学

T 804-8550 福岡県北九州市戸畑区仙水 1-1

Kyushu Institute of Technology.

1-1, Sensui, Tobata, Kitakyushu, Fukuoka, Japan 804-8550
式がある。電磁誘導方式は検出範囲が約数十 $\mathrm{cm}$ と狭い ため不発弾探査で部分的に使用される。差動型の磁気探 査方式は検出範囲が 4-6m と広いため, ほとんどの不発 弾探査で差動型の磁気探査方式が使用される。差動型の 磁気探査方式を用いた探査装置は磁気探査装置と呼ばれ る。近年の磁気探査装置による不発弾探査の問題として, 探査領域に隣接する構造物に使用されている強磁性体に よって頻発する不発弾の誤検知がある(5)。磁気探査装 置は 4-6m の検出範囲を持つため, 隣接エリアからの磁 界に反応して出力が増加し, 場合よっては不発弾よりも 大きな反応を検出する。その結果, 探査装置は誤った位 置に不発弾があると判断してしまい, 誤検知が発生する (6)。この問題を解決するために, 筆者らは複数の差動出

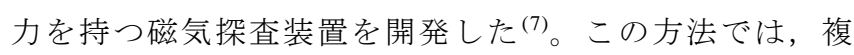
数の差動出力を用いることにより，隣接エリアから生じ る磁界の影響を低減している。しかしながら未だに問題 点も残されており, 隣接エリアからの磁界が強い場合や, 不発弾の大きさ, 距離の違いによっては検知が困難な場 合もある。そこで今回は, 2 つの差動出力の差と DOG フ 
イルタリングを用いることによって, 不発弾成分を強調 し, 不発弾検知精度をさらに向上する方法を提案し, そ の有効性をシミュレーションにより確認する。

\section{2. 原理}

\section{1 シミュレーション条件の設定}

図 1 は隣接エリアからの磁界の影響を示している。図 1 の斜線で示した部分が，隣接する構造物からの磁界の 影響によって誤検知が発生する領域である。図 1 の距離 $d$ は 4-6m である。この誤検知エリア下に不発弾がある場 合を想定し，図 2 のシミュレーションレイアウトを設定 した。ここでは線形双極子を $X$ 軸 $10 \mathrm{~m} の$ 位置に配置する。 この線形双極子は長さ $8 \mathrm{~m}$ とし, 両端にそれぞれ-0.3 $\mathrm{mWb}$ と $+0.3 \mathrm{mWb}$ の極を持っている。これを隣接エリア の鉄筋とする。さらに $X$ 軸 $11 \mathrm{~m}$, 鉄筋から $Y$ 軸距離 $2.0 \mathrm{~m}$ の位置に長さ $0.4 \mathrm{~m}$ ，両端にそれぞれ-0.2 $\mathrm{mWb}$ と +0.2 $\mathrm{mWb}$ の極を持つ強磁性体を追加する。この強磁性体をテ ストオブジェクトと呼び, 不発弾とみなす。本研究では このレイアウトでシミュレーションを行う。

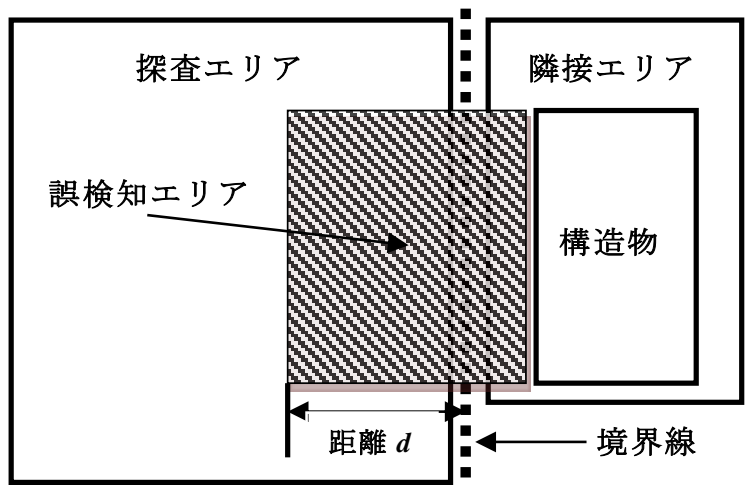

図 1 隣接エリアからの磁界の影響(7)

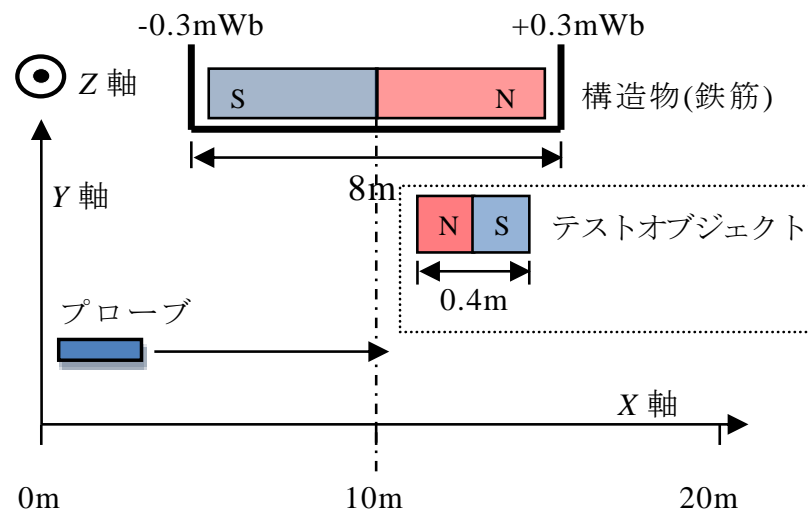

図 2 シミュレーションレイアウト図

\section{2 従来法の原理}

図 3 は磁気探査装置プローブの説明図である。図 2 に おいて図 3 のプローブを鉄筋から $Y$ 軸距離 4, 5, 6m で 通過させシミュレーションを行う。その際の差動出力 $D 1$ (図 3 における磁気センサ $S 1$ と $S 2$ の出力の差)及び $D 3$ (図 3 における磁気センサ $S 1$ と $S 3$ の出力の差)を図 4(a)-(c)に示す。図 4 において, 出力のマイナス值は $X$ 軸 のマイナス方向, 出力のプラス值は $X$ 軸のプラス方向と する。横軸を $X$ 軸方向の距離, 縦軸を磁界の強さとする。 図 2 のレイアウト図に示すように, $X$ 軸方向 $11 \mathrm{~m}$ の位置 にテストオブジェクトを配置している。差動出力 $D 3$ に 着目すると，図 4(a)では $D 3$ が $11 \mathrm{~m}$ の位置で出力がピー クとなり，テストオブジェクトを検知できる。しかし， 図 4(b)-(c)ではピークの位置が $11 \mathrm{~m}$ と異なっており，こ の出力による検知は困難である。

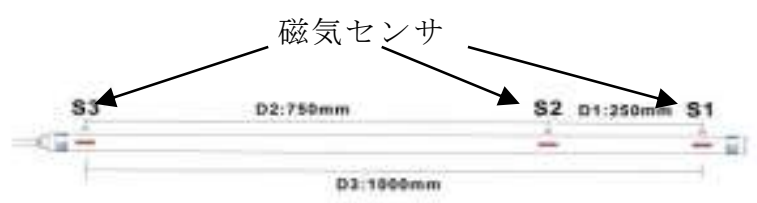

図 3 磁気探査装置プローブ(7)

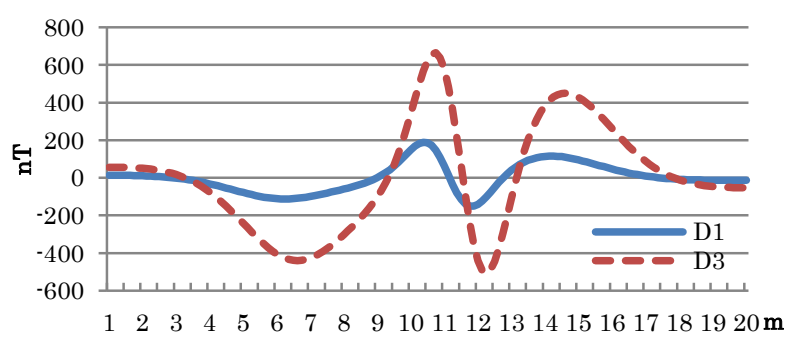

(a) $Y$ 軸距離 $4 \mathrm{~m}$

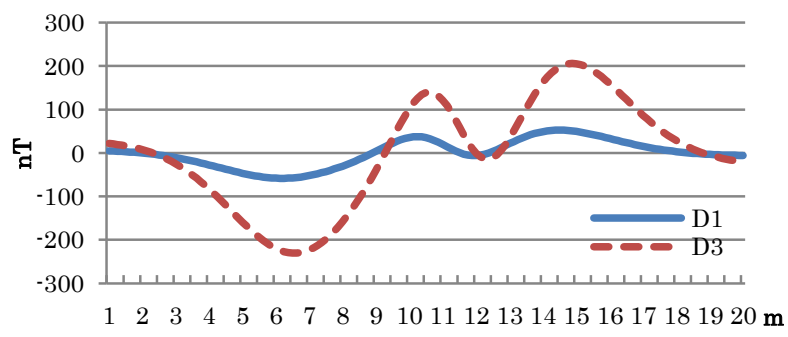

(b) $Y$ 軸距離 $5 \mathrm{~m}$

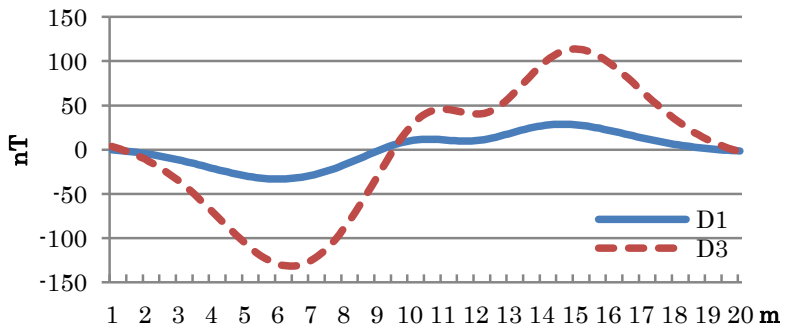

(c) $Y$ 軸距離 $6 \mathrm{~m}$

図 $4 D 1$ 及び $D 3$ の差動出力 
従来法は, 出力のピーク值があるしきい值を超えた場 合にテストオブジェクトがあると判定するものであり， 判定がシンプルで有効性が高い。しかし, 図 4(b)-(c)のよ うに $Y$ 軸距離が大きくなる場合やテストオブジェクトが 小さくなる場合に, $X$ 軸方向 $11 \mathrm{~m}$ 位置のピークが減少し 検知が困難になる。また，鉄筋からの磁界が強い場合に は $X$ 軸方向 $11 \mathrm{~m}$ 位置のピーク以外の成分が増大し, その 結果テストオブジェクトの検知が困難になる場合がある。

これら問題を解決するため, 鉄筋からの磁界成分によ る出力を減少させ, テストオブジェクト成分の出力を強 調する手法を研究する。

\section{3. 提案する手法}

ここでは，鉄筋とテストオブジェクトが複合する差動 出力では検知が困難になる問題を解決するため, 鉄筋成 分を減らしテストオブジェクト成分を強調する解析手法 の研究を行う。テストオブジェクト成分のみを強調する ために, 図 4 の差動出力から鉄筋成分とテストオブジェ クト成分の分離を検討する。

図 5 は, 図 4(b) と同一の位置関係において, 鉄筋のみ が存在する場合とテストオブジェクトのみが存在する場 合の差動出力 $D 3$ のシミュレーション結果である。図 5 では鉄筋の差動出力波形と比べ, テストオブジェクトの 差動出力波形の傾きが急峻であることがわかる。鉄筋は テストオブジェクトよりもプローブから離れた位置にあ り，磁界分布が緩やかになる。これは線形双極子を持つ 磁性体の磁界の強さがおおよそ距離の二乗の逆比例にな るためである ${ }^{(8)}$ 。鉄筋の場合は, 約 $X=6.5 \mathrm{~m}$ の地点で差 動出力がマイナスのピークとなっており，X=14.5m の地 点で差動出力がプラスのピークとなっており, $X=6.5 \mathrm{~m}$ か ら $14.5 \mathrm{~m}$ の間では出力が直線的に変化している。テスト オブジェクトの場合もマイナスのピークからプラスのピ ークまでの間の出力の変化がほぼ直線になっている。言 い換えると，この間では $X$ 軸方向の磁場勾配は一定とい える。

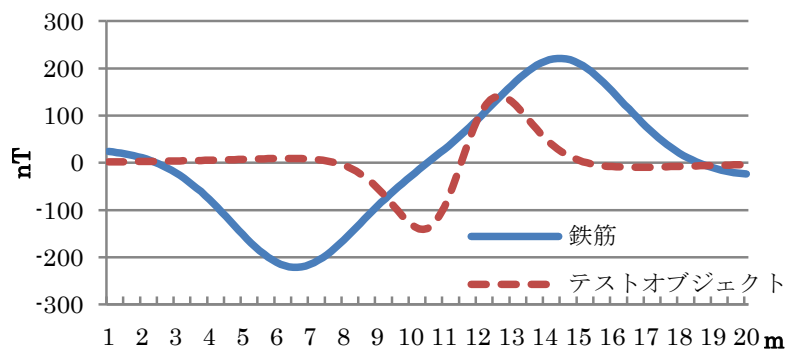

図 5 図 4(b)の個別 D3 差動出力

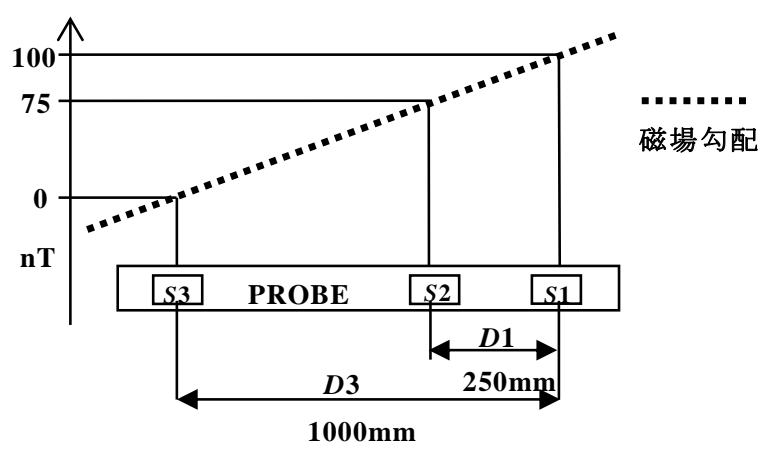

図 6 磁場勾配と差動出力の関係

次に, 図 3 のプローブが一定の磁場勾配下にある場合 の差動出力 $D 1, D 3$ の関係を図 6 に表す。図 6 では $D 1=S 1-S 2(25 \mathrm{nT}), D 3=S 1-S 3(100 \mathrm{nT})$ であり，一定の磁場勾 配下では $D 1: D 3=25: 100=1: 4$ となる。つまり，一定の 磁場勾配下では $D 3$ は $D 1$ の 4 倍の值を示す。

このことから，筆者らは鉄筋に起因する緩やかな変化を 取り除くために，新たに DOD 関数(差動出力の差 : Difference of Difference)を定義する。

$$
D O D(x)=D 3(x)-(4 \cdot D 1(x))
$$

図 4(a)-(c)の差動出力をこの DOD 関数で演算することに よって, 鉄筋成分を減らした分布が生成される。(結果は <4.1>節で示す。)

次に，その分布からさらにテストオブジェクト成分の みを強調するためのフィルタリングを検討する。次の図 7 は図 4(a)から鉄筋成分を取り除き，テストオブジェク 卜単体の差動出力で得られた $D 1, D 3$ を，式(1)の DOD 関数で演算した結果である。図 7 に示す DOD 関数によ る演算結果は, 画像処理分野でエッジ強調に使用される DOG 関数(Difference of Gaussian)と類似した分布となっ ている。そこで、今回のシミュレーションでは DOG 関 数を用いてテストオブジェクト成分の強調を行うことと する。式(2)に DOG 関数を示す ${ }^{(9)}$ 。

$$
\begin{aligned}
& D O G(x)=A\left\{G_{1}(x)-Q \cdot G_{2}(x)\right\} \\
& D O G(x)=A\left\{\exp \left(-\frac{x^{2}}{\sigma_{e}^{2}}\right)-Q \cdot \exp \left(-\frac{x^{2}}{\sigma_{i}^{2}}\right)\right\}
\end{aligned}
$$

図 8 に DOG 関数の波形分布を示す。なお，この図では 図 7 の出力波形に合うように $A, Q, \sigma_{e}, \sigma_{i}$ の值を設定 している。本研究では, DOD 関数で演算された分布を, DOG 関数で畳み込み積分する (DOGフィルタリングと呼 ぶ)。それによって，テストオブジェクト近傍の変化の大 きい波形はより強調され，周囲の緩やかな部分は押さえ られた分布が抽出されると見込まれる。その結果はく4.2> 節に示す。 


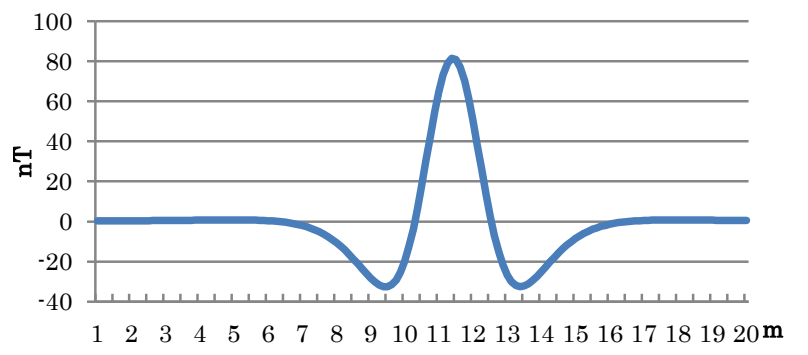

図 7 テストオブジェクト成分を DOD 関数で演算

( $Y$ 軸距離 $4 \mathrm{~m}$ )

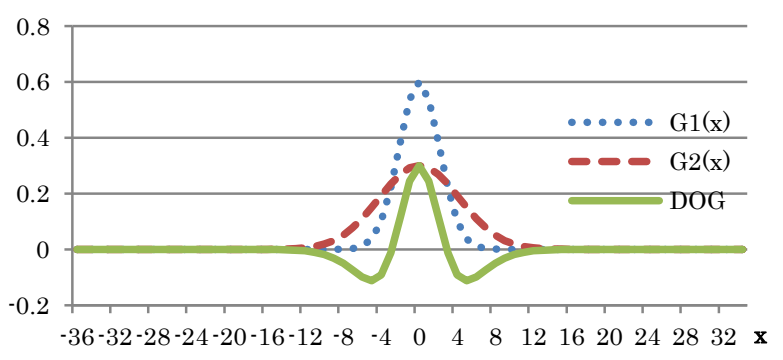

図 8 DOG 関数 $\left(A=1.2, Q=0.6, \sigma_{e}=3, \sigma_{i}=6\right)$

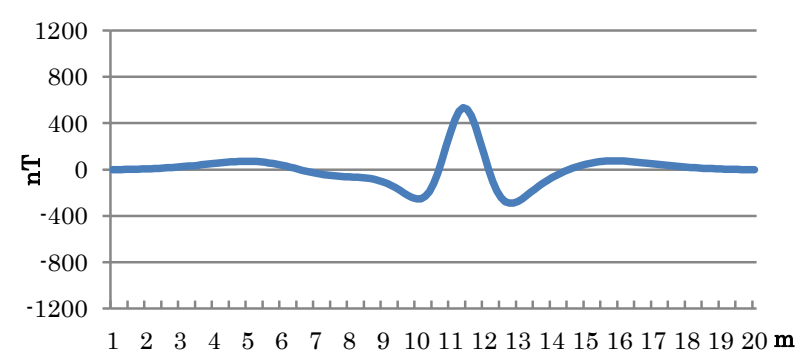

(a) $Y$ 軸距離 $4 \mathrm{~m}$

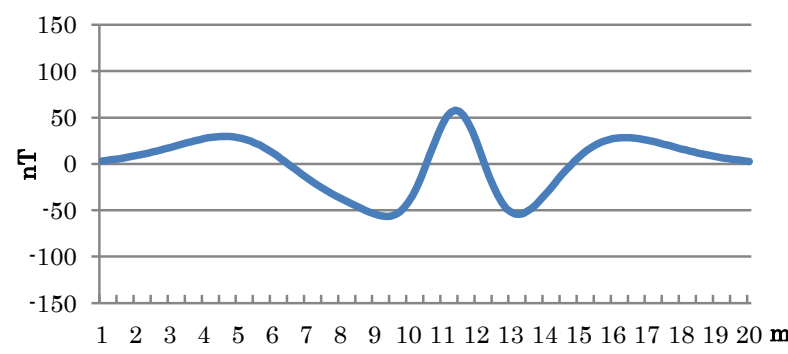

(b) $Y$ 軸距離 $5 \mathrm{~m}$

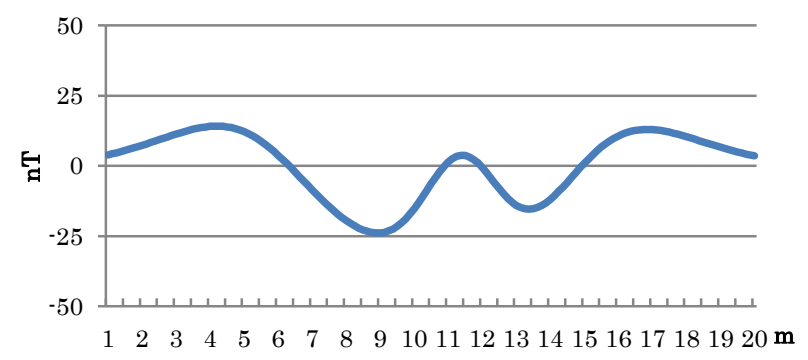

(c) $Y$ 軸距離 $6 \mathrm{~m}$

図 $9 D 1$ 及び $D 3$ 差動出力の DOD 関数演算結果

\section{4. 実験結果}

\subsection{DOD 関数の結果}

図 9(a)-(c)は図 4(a)-(c)をDOD 関数で演算した結果であ る。図 4 と図 9 を比較すると, 図 4(a)の D3 波形と図 9(a)
の波形ともにテストオブジェクトのある位置 $X=11 \mathrm{~m}$ で 波形の出力がピークとなっている。しかし, 図 4(b)のD3 の波形を見ると, $X=15 \mathrm{~m}$ の位置の出力が $X=11 \mathrm{~m}$ の出力 を上回っている。それに対し, 図 9(b)では DOD 関数の 効果によってテストオブジェクトの位置 $X=11 \mathrm{~m}$ のピー クが上回っている。しかし, 図 9(c) $Y$ 軸距離 $6 \mathrm{~m}$ におい ては, テストオブジェクト成分のピークは, その周囲よ り小さくなった。これは, テストオブジェクトの $Y$ 軸距 離が 5, 6m と離れることで, テストオブジェクトの磁界 も距離の二乗の逆比例で緩やかになるためと推測される。 次にさらに過酷な条件として, 図 2 において鉄筋の両 端にそれぞれ-0.6 mWb と+0.6 mWbの極を持たせ，鉄筋 からの磁界が 2 倍になった場合の差動出力を DOD 関数 で演算した結果を図 10 に示す。図 10(b)では図 9(b) と比 ベてテストオブジェクト成分 $X=11 \mathrm{~m}$ のピークは鉄筋成 分より小さくなり, 検知が困難になった。以上の結果か ら，(1) テストオブジェクトとプローブの距離が離れる $(Y$ 軸距離が大きくなる $)$ 場合と, (2) 鉄筋からの磁界が強 くなる場合は, DOD 関数によって得られた波形からテス トオブジェクトの位置を特定できていないことがわかる。

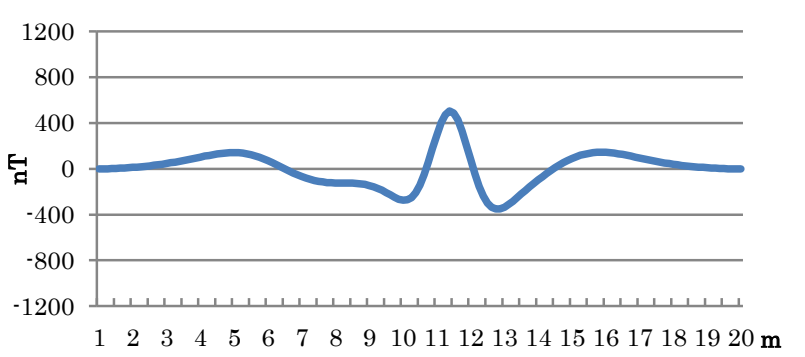

(a) $Y$ 軸距離 $4 \mathrm{~m}$

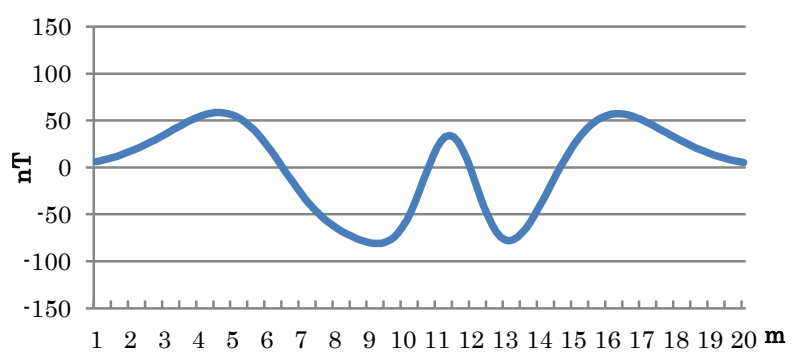

(b) $Y$ 軸距離 $5 \mathrm{~m}$

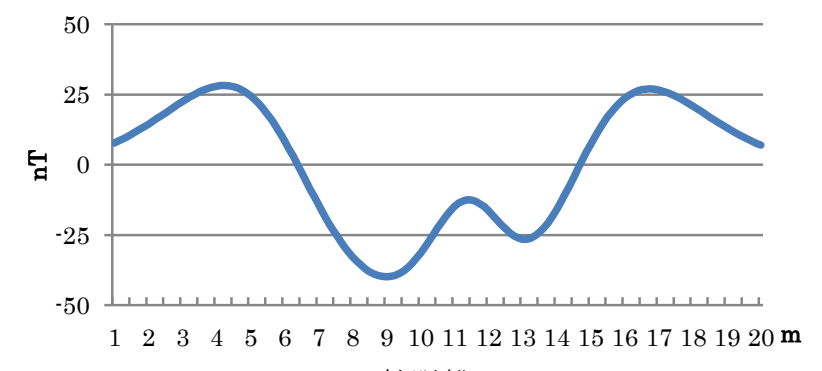

(c) $Y$ 軸距離 $6 \mathrm{~m}$

図 $10 D 1$ 及び $D 3$ 差動出力の DOD 関数演算結果 (鉄筋の磁界の強さ 2 倍) 
4.2 DOG フィルタリング

次にテストオブジェクト成分を強調するため, DOG フィ ルタリングを行う。図 11(a)-(c)は図 8 の DOG 関数を用い て, 図 9(a)-(c)の出力波形と畳み込み積分を行った結果で ある。図 9(a)-(c)と比べて図 11(a)-(c)では, テストオブジ エクトのある $X=11 \mathrm{~m}$ 近傍の出力が強調され, その周囲の 成分は減少していることが確認できる。図 9(c)ではテス トオブジェクトの位置の出力が周囲より小さくなってい たが, 図 11(c)ではテストオブジェクト位置の出力が周囲 を上回った。

次に，鉄筋からの磁界が 2 倍になった場合の DOG フ イルタリング効果を確認する。図 12(a)-(c)は図 8 の DOG 関数を用いて, 図 10(a)-(c)の出力波形と畳夕込み積分を 行った結果である。図 10(b)-(c)ではテストオブジェクト のある $X=11 \mathrm{~m}$ 近傍の出力が周囲成分より小さくなって いたが，図 12(b)-(c)では $X=11 \mathrm{~m}$ 近傍の出力が周囲の成分 を上回った。この結果，テストオブジェクトからプロー ブまでの距離が離れる場合(図 11)や，鉄筋からの磁界が 強くなる場合(図 12)でも, DOG フィルタリングによって, テストオブジェクトのある位置の出力がその周知出力を 上回ることがわかった。

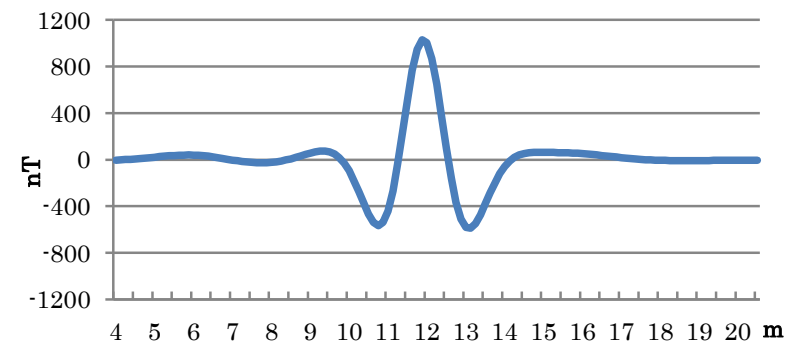

(a) $Y$ 軸距離 $4 \mathrm{~m}$

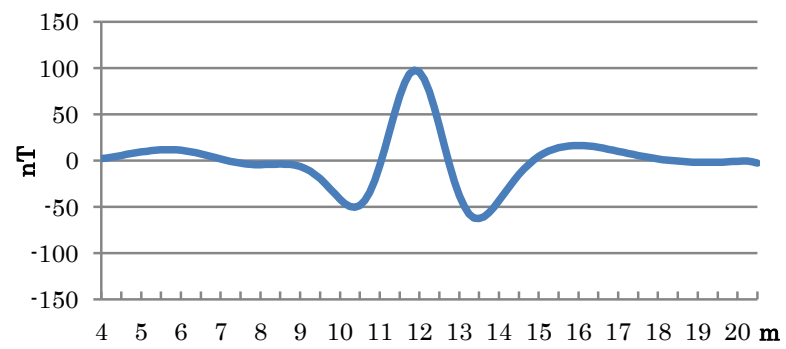

(b) $Y$ 軸距離 $5 \mathrm{~m}$

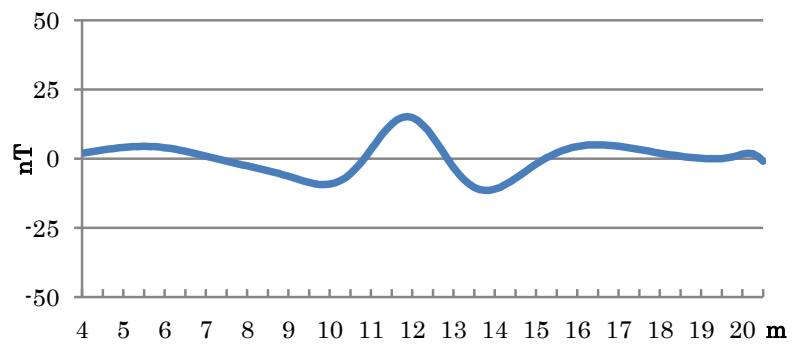

(c) $Y$ 軸距離 $6 \mathrm{~m}$

図 11 DOG フィルタリング結果

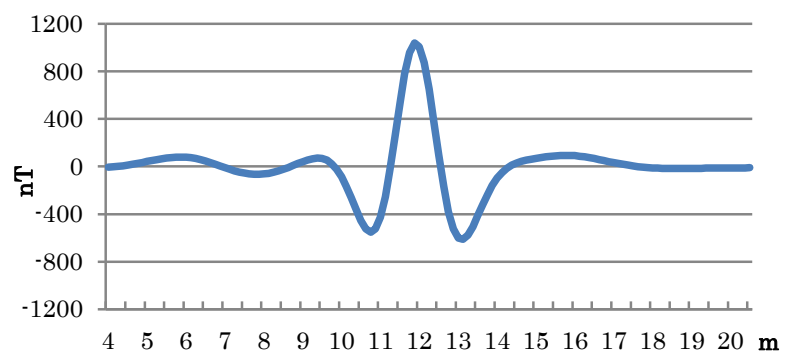

(a) $Y$ 軸距離 $4 \mathrm{~m}$

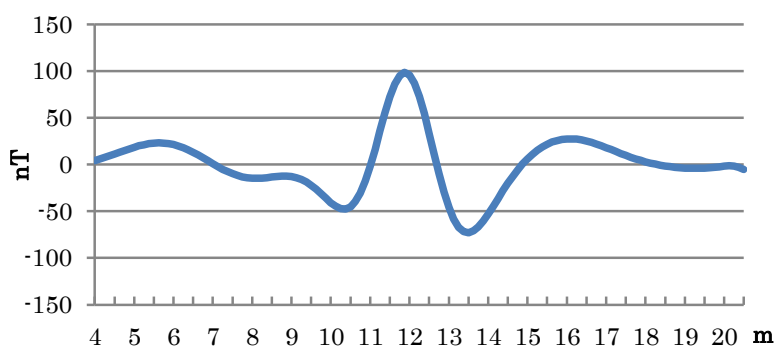

(b) $Y$ 軸距離 $5 \mathrm{~m}$

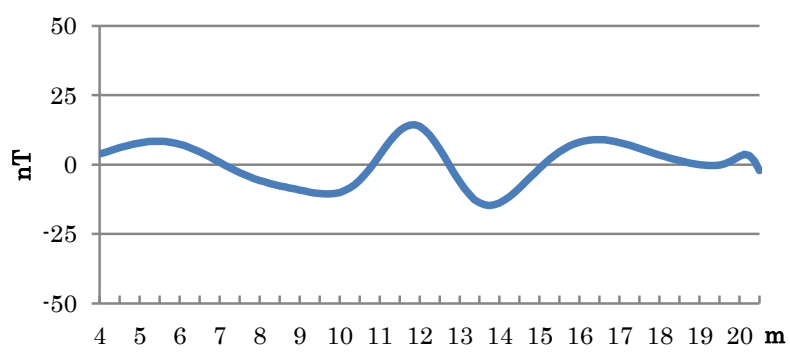

(c) $Y$ 軸距離 $6 \mathrm{~m}$

図 12 DOG フィルタリング結果 (鉄筋の磁界の強さ 2 倍)

5. DOG フィルタリングの応用

次に図 2 において，テストオブジェクトの大きさを $1.5 \mathrm{~m}$ に変更した場合の DOG フィルタリングの効果を確 認する。この際 $1.5 \mathrm{~m}$ のテストオブジェクトには， $Y$ 軸距 離 $5 \mathrm{~m}$ において $0.4 \mathrm{~m}$ のテストオブジェクトと同等の磁界 分布となるように，両端に-0.055 $\mathrm{mWb}$ と+0.055 $\mathrm{mWb}$ の 極を持たせた。図 13(a)-(c)はその際の差動出力を DOD 関数で演算した結果である。図 13(c)では, 図 9(c) と同様 にテストオブジェクト成分のピーク值が周囲より小さく なっている。

次に図 13(a)-(c)に図 8 の DOG 関数を用いてフィルタリ ングを行ったものが図 14(a)-(c)である。テストオブジェ クトの大きさが変わってもテストオブジェクト成分のピ ークが周囲成分を上回った。しかし，テストオブジェク 卜成分のピーク值は, 図 9(a)から図 11(a)で 1.92 倍とな っている。これに対して，図 13(a)から図 14(a)では 1.66 倍と強調効果が低下した。これは，テストオブジェクト のサイズが $0.4 \mathrm{~m}$ から $1.5 \mathrm{~m}$ に大きくなったにも関わらず， DOG 関数の分布の広がりを変更していないためである。 


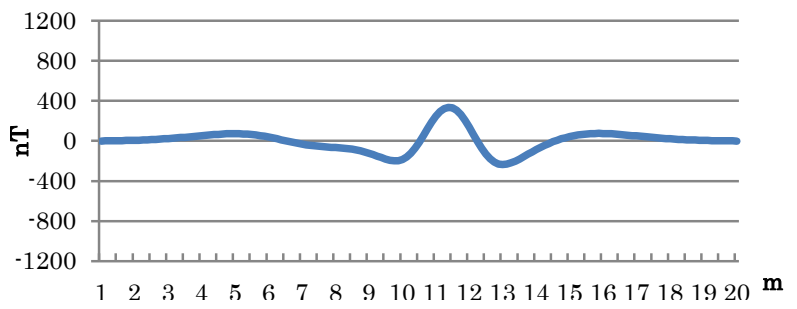

(a) $Y$ 軸距離 $4 \mathrm{~m}$

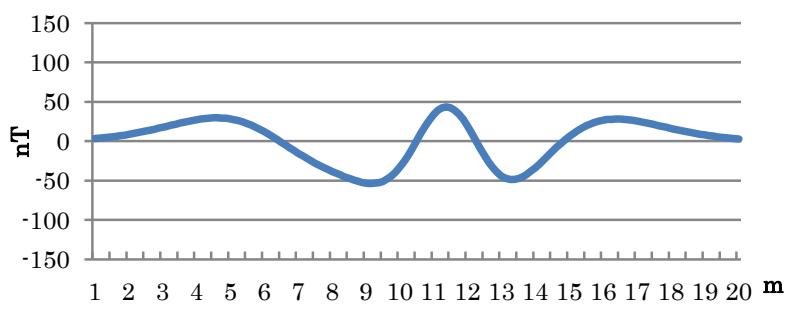

(b) $Y$ 軸距離 $5 \mathrm{~m}$

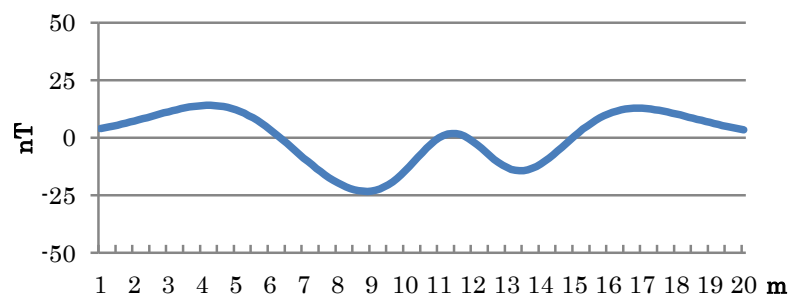

(c) $Y$ 軸距離 $6 \mathrm{~m}$

図 $13 D 1$ 及び $D 3$ 差動出力の DOD 関数演算結果 (テストオブジェクトの大きさ $1.5 \mathrm{~m}$ )

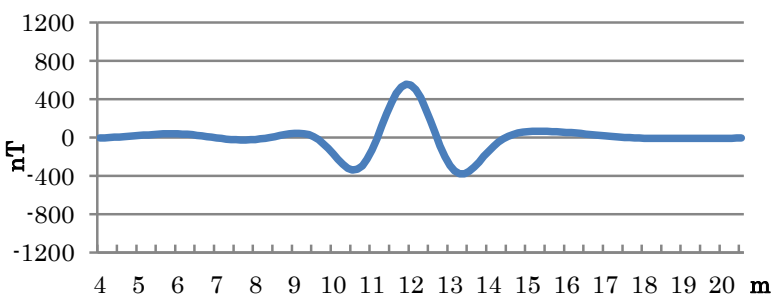

(a) $Y$ 軸距離 $4 \mathrm{~m}$

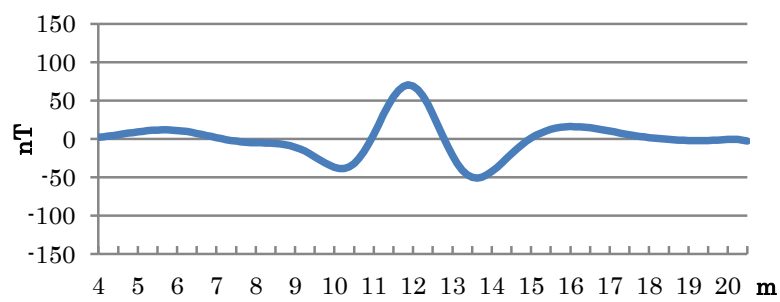

(b) $Y$ 軸距離 $5 \mathrm{~m}$

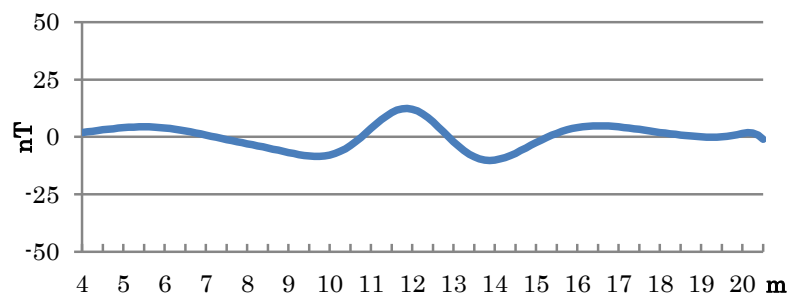

(c) $Y$ 軸距離 $6 \mathrm{~m}$

図 14 DOG フィルタリング結果

(テストオブジェクトの大きさ $1.5 \mathrm{~m}$ )
そこで，図 15 に示すように，1.5m のテストオブジェ クトの $Y$ 軸距離 $4 \mathrm{~m}$ に合わせて, DOG 関数の広がりを変 更した。図 16 は図 13(a)-(c) を図 15 の DOG 関数を使用 して畳み込み積分を行った結果である。図14(a)ではテス トオブジェクト成分のピークが図 13(a)から 1.66 倍にな ったが, 図 16(a)では 2.61 倍となった。図 14 と図 16 の 結果から，テストオブジェクトの大きさ，位置，に合わ せて DOG 関数を最適化することでフィルタリングの効 果が変わることが確認できた。逆に言えば，最適なフィ ルタサイズを見つけることによって，テストオブジェク テストのサイズを推定できる可能性がある。これについ ては今後さらに検討する必要がある。

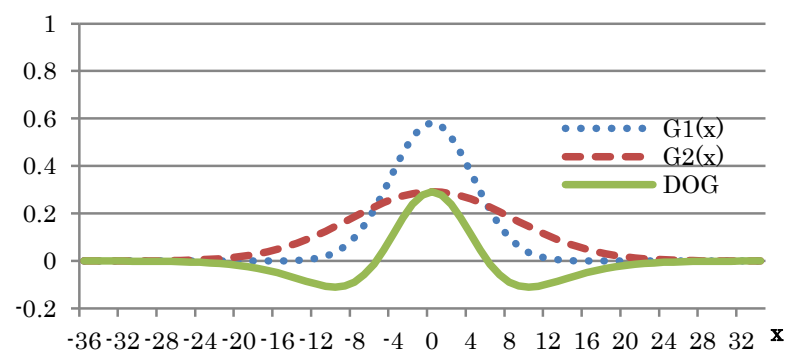

図 $15 \mathrm{DOG}$ 関数 $\left(A=0.58, Q=0.29, \sigma_{e}=6, \sigma_{i}=12\right)$

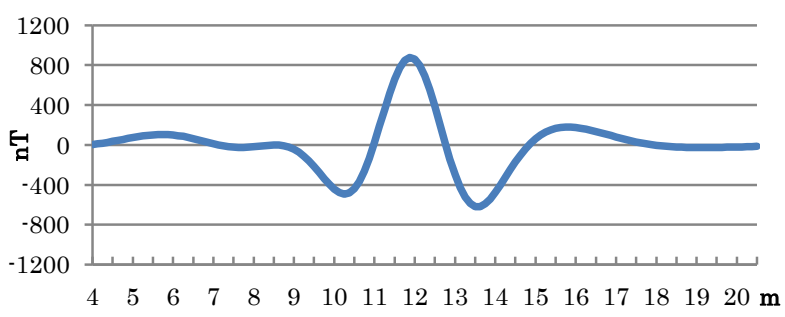

(a) $Y$ 軸距離 $4 \mathrm{~m}$

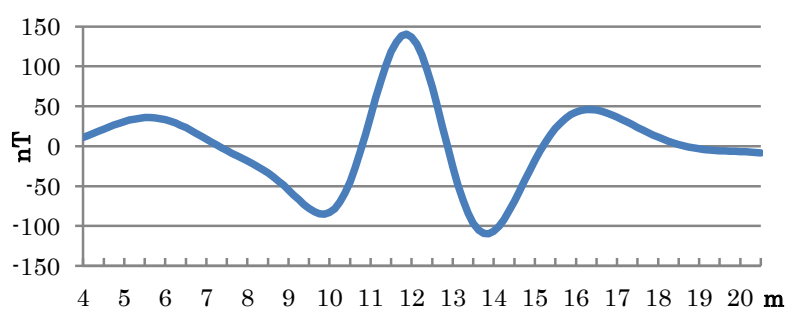

(b) $Y$ 軸距離 $5 \mathrm{~m}$

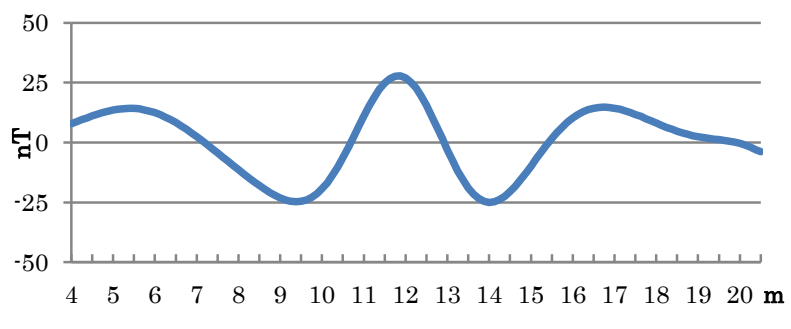

(c) $Y$ 軸距離 $6 \mathrm{~m}$

図 16 図 15 のDOG 関数による DOG フィルタリング結果 (テストオブジェクトの大きさ $1.5 \mathrm{~m}$ ) 


\section{6. 結論}

本研究では, 異なる距離で構成された複数の差動出力 を持つ磁気探査装置の探查能力の向上を提案した。本手 法では磁気探査装置の差動出力 $D 1, D 3$ に対し, DOD 関 数による演算を行い, これによって得られた結果に, DOG 関数を用いてフィルタリングした。この手法を用い て, 隣接エリアからの磁界の影響による誤検知エリア下 において, 従来は検知できなかった不発弾を検知できた。 これにより, 本手法による磁気探査装置の探査能力の向 上が確認できた。

今後は, テストオブジェクトの大きさ, 位置, 方向に 合わせたフィルタ設定のデータベース化を進めることで, 装置による不発弾の大きさや位置の自動判別を目指した い。

\section{文献}

（1）統合幕僚監部:「平成 24 年度災害派遣及び不発弾処理実績」, 統合 幕僚監部報道発表資料, pp. 8-9, 2013

（2）沖縄県知事公室防災危機管理課: 「住宅，アパート，マンションな どの建築を考えている皆様へ」，小冊子，pp. 1-5，2013

（3）沖縄県不発弾等対策協議会事務局:「不発弾等爆発事故防止に向け て」，沖縄不発弾等対策協議会説明会，pp. 3-6，2009

(4) 内閣府沖縄総合事務局:「沖縄における不発弾対策の取り組み」, 定 例会見資料, pp. 9-11，2013

（5）沖縄県農林水産部: 磁気探査業務共通仕様書」, 共通仕様書, pp. $13-14,2011$

(6) 義井扸影:「磁気工学」, 海文堂, pp. 283-284, 1969

(7) 川野広志, 芹川聖一:「不発弾探查のための差動磁気センサ型磁 気探查装置の改良」, 産業応用工学会論文誌, Vol. 1, No. 2, pp.47-51, 2013

(8) Avrin, William F. and Sager, Ronald E. : "An optically pumped magnetic sensor with submilligamma resolution”, IEEE Transactions on Magnetics, Vol. 25, No. 5, pp. 3408-3410, 1989

（9）芹川聖一, 下村輝夫：「網膜に類似した処理による光沢知覚シミュ レーション」, 電気学会論文誌, Vol. C-113, No. 11, pp. 1023-1029, 1999

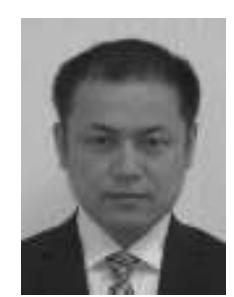

川野 広志

1997 年 3 月北九州工業高等専門学校電子制御科 卒業。同年 4 月株式会社エムティアイ入社，現在 に至る。磁気センサ技術の研究に従事。

\section{芹川 聖一}

（正員） 1961 年生。1986 年 3 月熊本大学 大学院工学研究科電子工学専攻修了。同年東 京エレクトロン（株）入社。1990 年 2 月九 州工業大学工学部助手, 2000 年 4 月同大学 助教授, 2004 年同大学教授, 現在に至る。 知能情報処理, 知的センシングの研究に従 事。工学博士。電子情報通信学会会員。 